\title{
Press Information on Activities of Ministers of Education of Bulgaria, Sweden and Hungary Visiting Poland in 1935
}

\begin{abstract}
The renascent Polish state was being built in the interwar period (1918-1939), developing its position on all possible levels in the international arena. One of these was education and culture. Poland signed a lot of international agreements in this field. This was connected with visits by our ministerial representatives to other countries and with arranging visits in Poland for guests from different countries. In 1935, three ministers of education from abroad visited Poland: Todor Radev (Bulgaria), Artur Engberg (Sweden) and Bálaint Hóman (Hungary). The purpose of the visit of the first two ministers was the signing of the Polish-Bulgarian and Polish-Swedish cultural agreements. The Hungarian minister of education came to Poland to assess the implementation of the agreement which had been signed between Poland and Hungary a year before.

While staying in Poland, beside official meetings with the President and the Ministers of education and foreign affairs, our guests visited various educational institutions in cities such as Warsaw, Krakow, Poznań or Vilnius. The press took a lively interest in those visits, reporting them on an ongoing basis. Apart from news reports, also editorials and even articles were published. These were devoted to some of the educational and cultural issues of our guests' countries.
\end{abstract}

Keywords: minister of education, press, foreign visit, foreign cooperation, Bulgaria, Sweden, Hungary, Poland

After over 120 years of captivity, Poland as a country had to restore its international relations on various levels: political, economic or cultural and educational. No wonder that representatives of the Polish government both often visited other European countries and hosted foreign guests in Poland. Several times, Poland hosted visits paid by ministers of education, including by: Constantin Angelescu (Romania) ${ }^{1}$, Kuno Klebersberg (Hungary)

${ }^{1}$ More on the topic in: GOŁDYN, P., Wizyta ministra oświaty Rumunii Constantina Angelescu w Polsce w 1937 r. w świetle ówczesnych doniesień prasowych, [in:] Polsko-rumuńskie związi historyczne i kulturowe, ed. S. IACHIMOVECHI, E. WIERUSZEWSKA-CALISTRU, Suceava 2013. 
and Uuno Yrjo Hannakla (Finland). Angelescu visited Poland in 1937, Klebersberg in 1931 and Hannakla in 1938.

All these visits had a similar purpose, namely the signing or implementation of an agreement on cultural, scientific and artistic cooperation between Poland and the state whose representative visited the Republic of Poland. Each time, both parties emphasized the importance of the visit and its significance for mutual relations.

In this respect, the most special was the year 1935, when a visit to the reborn Polish state was paid, at different times, by three ministers of education of European countries. The first one was the Bulgarian Minister of Education Todor Radev who came to Poland in April 1935. Two months later, a visit was paid by his Swedish counterpart, Artur Engberg. In November of that year, the Hungarian Minister of Education, Bálint Hóman, spent a few days in Poland.

Such events could not be left unnoticed by the press, which very often quite eagerly recorded the whole course of the visits, all the meetings, speeches, etc. The agendas of the visits were similar and the mentioned ministers most often visited the same cities: Warsaw, Krakow and Poznań. The Hungarian minister also visited Vilnius for one day. That is why the newspapers published in these cities, such as "Kurier Warszawski", "Ilustrowany Kurier Codzienny", “Czas”, "Dziennik Poznański” and "Kurier Poznański”, were especially subject to our analysis.

Other newspapers were also analysed as an auxiliary source, for example those published in Lvov or Łódź: "Gazeta Lwowska", "Echo" and "Ilustrowana Republika". Thus, it was possible to determine the degree of interest in a given visit to those cities which did not host foreign delegations. As far as the professional pedagogical press is concerned, these visits were recorded mainly in "Oświata i Wychowanie", a journal issued by the Ministry of Religious Denominations and Public Enlightenment.

Hence, the press became the main and basic source to analyse the course of these visits. As noted by Iwona Michalska, based on earlier studies by Marceli Handelsman and Stanisław Kościałkowski, the press becomes an important element of study of the history of education when other sources are absent ${ }^{2}$.

\section{Visit of the Minister of Education of Bulgaria Todor Radev}

The Minister of Education of Bulgaria visited Poland on 7-12 April 1935. "Ilustrowana Republika", a Łódź newspaper, announced the visit as follows: The Bulgarian Minister of Education, General Todor Radev is to arrive in Warsaw on Sunday, 7 of April. A number of receptions and ceremonies are planned on the occasion of the Minister Radev's stay and intended signing of the Polish-Bulgarian cultural agreement. Minister Radev will stay

\footnotetext{
2 MICHALSKA, I., Wybrane problemy metodologiczne wykorzystywania prasy jako źródła w badaniach historii wychowania, [in:] Źródła w badaniach naukowych historii edukacji, ed. W. SZULAKIEWICZ, Toruń 2003, pp. 127-144.
} 
in the capital city for three days, and thereafter he will go to Krakow in the company of Minister Jędrzejewicz ${ }^{3}$.

"Dziennik Poznański" noted that while the Minister Radev's trip would not be considered an official visit, it was nonetheless crucial from the point of view of Polish-Bulgarian relations. These relations were described as positive from the very beginning of the independence of the Polish state. The author of this article called the Bulgarians a "brother nation". At the same time, he described the political situation taking place in that country at the time. In 1934, a military coup occurred there: to oppose parliamentary corruption and outdated methods of government, from which communist and revolutionary circles benefited. Minister Radev was a member of the government established after the coup d'état in agreement with the King of Bulgaria Boris III $^{4}$.

The same article outlined the goals for which the cultural agreement with Bulgaria was to be signed, namely: the exchange of students and professors, organisation of lectures and exhibitions, scholarships and apprenticeships. This new type of bilateral agreements was conceived by Poland and enormously contributes, through constant government assistance in this field, to our cultural penetration in the era of economic crisis, which hinders private contacts with foreign countries.

The importance of this convention was referred to by Todor Radev who, when on the way to Poland, issued in Székesfehérvár a statement as follows: I am travelling to Warsaw to sign the Polish-Bulgarian convention on cultural cooperation. I hope this convention will be beneficial for both our brother nations. The convention was prepared by my predecessor, Minister Molov. The convention will provide the foundation for cooperation not only for educational institutions, but also for personal relationships and mutual visits by Polish and Bulgarian students ${ }^{5}$.

As regards cultural contacts between both countries, a major role was played by the Bulgarian-Polish Society based in Warsaw, which on its own initiative sought to raise funds for scholarships for Bulgarian students studying in Poland. In Bulgaria, on the other hand, also communities of polonophiles were active, including in Varna, where an initiative was established to erect a monument to King Władysław of Varna, which initiative was also supported in Poland. It was an independent initiative of the Bulgarians. It was speculated that the ceremony of unveiling the monument would be attended by Wacław Jędrzejewicz, the Polish minister for religious denominations and public education. $\mathrm{He}$ indeed had promised to pay a return visit to Bulgaria ${ }^{6}$. It was also expected that several Polish-Bulgarian and Bulgarian-Polish associations of a cultural and scientific character would be established as a result of signing the agreement ${ }^{7}$.

\footnotetext{
3 "Bułgarski minister przyjeżdża do Warszawy", Ilustrowana Republika 1935, no. 96, p. 3.

${ }^{4}$ KORDECKI, K., “Polska-Bułgarja”, Dziennik Poznański 1935, no. 83, p. 3.

5 “Oświadczenie min. Radewa”, Czas 1935, no. 98, p. 2.

${ }^{6}$ KORDECKI, K., op. cit., p. 3.

7 “Podpisanie polsko-bułgarskiej umowy kulturalnej”, Goniec Częstochowski 1935, no. 84, p. 3.
} 
The very arrival was reported as follows: On Sunday, 7 day of this month, the Bulgarian Minister of Education, General Todor Radev, came to Poland for a few days'stay. He was greeted at the border station of Zebrzydowice by Counsel E. Zdrojewski on behalf of the Minister of Religious Denominations and Public Enlightenment, and the Secretary of the Bulgarian Diplomatic Mission in Warsaw, Stoikov. Minister went on his way to Warsaw in a lounge railway car in the company of the above people, and he arrived in Warsaw at 11:05 p.m. At the train station, he was welcomed by Minister of Religious Denominations and Public Enlightenment Mr. Wactaw Jędrzejewicz in the company of deputy ministers: Father Żongołtowicz and Professor Chylinski and senior officials of the ministry, members of the Bulgarian diplomatic mission in Warsaw led by the Chargé d'Affaires Mr. Altinov, deputy commander of the city, Major Czuruk, representatives of the Ministry Foreign Affairs: Councillor Morstin and Councillor Poninski, the presidium of the PolishBulgarian Society with its President, Mr. Grostern, and representatives of the Bulgarian diaspora. Minister Radew is accompanied by the deputy head of the culture department of the Bulgarian Ministry of Education, Mr. Piriyov. It is planned that Minister Radev will be received tomorrow by the Minister of Religious Denominations and Public Enlightenment Jedrzejewicz, the Prime Minister and the Minister of Foreign Affairs, and that he will sign the Polish-Bulgarian convention on cultural cooperation, and then Minister Beck will entertain the honourable guest at a breakfast. In the afternoon there will be a tour of Warsaw, and in the evening, Minister Jedrzejewicz hosts a dinner, after which the evening reception will take place . $^{8}$

The first day of the visit began with a ceremony of wreath laying on the Tomb of the Unknown Soldier. Minister Radev was accompanied in this act of homage by the deputy head of the department of culture of the Bulgarian Ministry of Education Danko Piryov. The ceremony was prepared by soldiers from the 30th Rifle Regiment "Kaniów" When the Minister came to the Pitsudski Square, the military band welcomed him with the Bulgarian national anthem. Then Minister T. Radev, having received the report from the commander of the 30th Rifle Regiment, Col. Eng. Janusz Grzędzinski, passed in front of a company from the 30th Rifle Regiment While laying the wreath, the band played the Polish national anthem. Having signed the memorial book, Minister Radev, celebrated by playing the General's March, walked along the company from the 30th Rifle Regiment. The ceremony held at the Pilsudski Square was attended, among others, by Minister W. Jędrzejewicz and the President of the Polish-Bulgarian Society Jan Dębski.

On the same day, official meetings took place. The first one was with the Minister of Education W. Jędrzejewicz. Later on, Radev met with Prime Minister Walery Sławek and Minister of Foreign Affairs Józef Beck. It was the premises of the Ministry of Foreign Affairs where the Polish-Bulgarian cultural convention was signed. Then less official meetings were held, such as the breakfast hosted by J. Beck in honour of the Bulgarian

\footnotetext{
8 “Bułgarski minister oświaty przybył wczoraj do Polski”, Ilustrowana Republika 1935, no. 97, p. 2.

9 “Pierwszy dzień pobytu”, Czas 1935, no 98, p. 2.
} 
guest, a tour of the city, and finally the dinner and reception at the W. Jędrzejewicz's residence $^{10}$.

The agenda included such items as: visiting the military airfield (after all, Radev was a general) in the company of General Rayski. Accompanied by Minister Jędrzejewicz, they visited the President Narutowicz Campus (Kolonia Akademicka im. prezydenta Narutowicza). After these visits, as mentioned earlier, a dinner was held with Minister Jędrzejewicz, during which Radev gave a speech in which he stressed that the signed Convention on Cultural Cooperation between Bulgaria and Poland was the result of centuries - long effort for "bringing the split-up Slavs together again", but also a result of the long-standing Polish-Bulgarian cooperation. He also said at that moment: I came to Poland to see the results of this cooperation and find ways to enhance the area for future results. The tomb of your king, fallen 500 years ago near Varna, is a temple for us today. We are building a mausoleum where both Bulgarians and Poles could pay a tribute to him. A lot of Poles took part in the struggle for regaining independence by Bulgaria ${ }^{11}$.

Minister Radev also said that works by Henryk Sienkiewicz are very popular in Bulgaria, and that whole generations of Bulgarian young people were formed and educated with his novels. Also, similar influence was asserted by Władysław Reymont, who was the first chairman of the Polish-Bulgarian Society established in 1921. After this address and a toast in honour of President I. Mościcki and Minister W. Jędrzejewicz and "for the prosperity of the Polish nation", Jędrzejewicz spoke: having the honour of hosting for the first time the Minister of Education of the Kingdom of Bulgaria, I recall with joy and pride that the first Bulgarian secondary school, whose graduates included a whole company of fighters, was founded by people coming from Poland and welcomed in Bulgaria with extraordinary hospitality. The agreement with Bulgaria, corresponding to the needs of broad circles both in Bulgaria and Poland, will result in stable and systematic exchange of spiritual values, thanks to government support (exchange of professors and students, support for historical and language studies, organization of exhibitions, etc.). While wishing further development and deepening of our friendly relations, I am raising this chalice in honour of His Majesty King Boris III, for the prosperity of Bulgaria and to your health, Minister $^{12}$. Minister Radev added that Polish-Bulgarian cooperation, not only in cultural terms, dated back to 1444, the time of the Battle of Varna. He also added that the agreement signed on that day was a deliberate act resulting form the circumstances of the time. It was an act embodying the idea that had been in the consciousness of both nations for many centuries ${ }^{13}$.

The Bulgarian minister spent the third day of the visit to Poland visiting schools and scientific institutions. He was accompanied by Minister Wacław Jędrzejewicz in these activities. Members of the Bulgarian mission were present also. The first institution vis-

\footnotetext{
10 “Minister Radew gościem Rządu polskiego", Dziennik Poznański 1935, no. 83, p. 3.

11 “O ożywienie wymiany kulturalnej polsko-bułgarskiej”, Dziennik Poznański 1935, no. 84, p. 2.

12 Ibidem, p. 2.

13 “Min. T. Radew w Warszawie”, Kurier Warszawski 1935, no. 98, p. 3.
} 
ited by the delegation was Państwowy Instytut Wychowania Fizycznego (the National Institute of Physical Education). The Bulgarian delegation learnt in detail about the structure of the university, and became familiar with its organization and tasks. From the district of Bielany, Minister Radev went to Hoża Street, where he visited Państwowa Szkoła Techniczna (the State Technical School). He was especially interested in such departments as: automotive and air department, aviation department and road department. The young people who were studying in this institution gave the Bulgarian minister many souvenirs and exhibits made by themselves. In this school, the delegation was joined by the Warsaw school district superintendent, Ignacy Pytlakowski. The next item of the agenda was a visit to the Warsaw University of Technology. Here, Minister Radev was accompanied by the rector of this university, Edward Warchałowski. In the afternoon, the Bulgarian delegation left for Krakow ${ }^{14}$.

Even before his departure to Krakow, Minister Radev was interviewed by a representative of Polska Agencja Telegraficzna (Polish Telegraph Agency). He referred to the bonds of friendship linking both nations and their historical background. It is worth recalling: The sources of this fellow feeling should be sought in a distant era, when Polish King Władystaw III led his army against the Turks to stop the invasion posing a threat to all Europe. The death of this heroic king in Bulgaria sealed the Polish-Bulgarian brotherhood [...]. The Polish-Bulgarian rapprochement has become even closer during our cultural and political resurrection. Immigrants from Poland showed deep fellow feelings for Bulgaria. They often acted as defenders of persecuted Bulgarians. Among the Polish émigré was Jeż-Miłkowski, who in his works tackled topics taken from the Bulgarian and Serbian history. The most important fact in the development of the Polish-Bulgarian rapprochement is the participation of Czajkowski in the life of our country. As an inspector of the Ottoman Empire, Sadyk Pasha (Czajkowski) worked on the equal rights for the Bulgarians. In Constantinople, Czajkowski, as a friend of the Bulgarian apostles of national rebirth, advises and guides them in the struggle for national ideals. The Cossacks were so popular among the Bulgarians that they were called "our army." The name of Mickiewicz is closely related to our country. He spent 10 days in Burgas, where Czajkowski's troops quartered. In his memoirs, Mitkowski talks with affection about the participation of the Bulgarian diaspora in the funeral of Mickiewicz. A friend of Bulgaria was poet Tadeusz Miciński, a close friend of our poet Pencho Slaveykov. In recent times, cultural relations between Bulgaria and Poland have been developing very quickly. Numerous Polish literary works have been translated into Bulgarian. From 1900 to 1933, 78 literary works written by 21 Polish authors were made known to Bulgarian literature. Our journals include numerous studies in the field of Polish art and poetry. Briefly speaking, the Polish nation, whether in social or political terms, or in terms of its literature, has always been a brotherly people to us, to whom we owe much ${ }^{15}$.

\footnotetext{
14 “Min. Radew w Polsce”, Kurier Warszawski 1935, no. 100, p. 3.

15 Ibidem, p. 3.
} 
These words confirm earlier statements given by Minister Radev about the importance of Polish-Bulgarian cooperation. They also confirm the fact that this contract was not a spontaneous act, but thought out and needed by both countries.

Representatives of the Bulgarian and Polish Ministries of Education arrived in Krakow on 7 April, almost half an hour before midnight. They were welcomed at the station by, among others, the Voivode (Governor) of Krakow, Mikołaj Kwaśniewski, the City Mayor, Mieczysław Kaplicki, the Rectors of all Krakow's universities and the superintendent of the Krakow school district Marian Godecki. As noted by a journalist of "Ilustrowany Kurier Codzienny", the Bulgarian guests will probably spend two days in Krakow, visiting the monuments and memorabilia of the city of Piast and Jagiellon dynasties ${ }^{16}$.

The visit to Krakow had a very pleasant aspect for Minister Jędrzejewicz. He was awarded a diploma of honorary member of Bratnia Pomoc Studentów Uniwersytetu Jagiellońskiego (Organisation for Mutual Assistance between Students of the Jagiellonian University). The ceremony, which took place in the "ancient arcaded courtyard" of the Jagiellonian Library, was also attended by Minister Radev. Afterwards, both ministers signed the memorial book of the Organisation for Mutual Assistance between Students of the Jagiellonian University, and then went to the "oldest Polish high school", i.e. Gimnazjum im. Nowodworskiego (the Nowodworski High School) at Plac Groble in Krakow. Boy scouts were waiting for the guests at the ground floor of the building while students who were members of various organizations active in the school: the Red Cross, Liga Obrony Przeciwlotniczej i Przeciwgazowej (Air and Chemical Defense League) and Liga Morska i Kolonialna (Maritime and Colonial League) stood along the stairs. The proper greeting took place in the auditorium in which the school orchestra played the Polish anthem. Then the Headmaster Lewicki spoke to the guests as follows: Your Excellencies, Honourable Ministers! The school, on behalf of which I have the honour to welcome you, Minister, is the oldest high school in Krakow and Poland, which has operated ceaselessly from the second half of the sixteenth century. One of the graduates from this ancient Polish school is King Jan Sobieski, the great and magnificent vanquisher of the Turks at Vienna. There are a lot of excellent men who left our school and whose activity has been written on the pages of our history. They also include a brilliant Polish poet, Stanisław Wyspiański, who foresaw and foretold the freedom of our State and became the most glorious word for our day - just as Marshal Pitsudski is for our generation the symbol of action. When greeting you within the walls of our school, I am pleased to get back to the nicest personal memories that we took from our memorable trip to Bulgaria in 1927. By welcoming you, Minister, with utmost affection, we also bow to the admirable irrepressibility of the Bulgarian people for whom we want to be cordial brothers ${ }^{17}$. At the end, the headmaster shouted in honour of the Bulgarian people, King Boris III and Minister Radev. After that, the school orchestra played the Bulgarian anthem "Shumi Maritsa".

16 “Min. gen. Radew i min. Jędrzejewicz przybyli do Krakowa”, Ilustrowany Kuryer Codzienny 1935, no. 102 , p. 16 .

17 "Minister bułgarski w najstarszem gimnazjum Polski", Ilustrowany Kuryer Codzienny 1935, no. 103, p. 16. 
Minister Radew thanked both the headmaster and the school students for their warm welcome and hospitality. By these words, the minister won over even the greater liking of students and school teachers. The school choir sang two Polish patriotic songs: Wyleć orle (Fly, white eagle) and Święta miłości kochanej ojczyzny (Oh, Sacred Love of the Beloved Country). One of the students, a certain Opałek, took the floor and asked Minister Radev to give greetings to Bulgarian young people and presented the ideology of Polish youth. Both ministers were presented flowers and signed the memorial book. The friendly atmosphere made the visit significantly prolonged, as noted by one of the journalists. The stay of the Ministers prolonged unexpectedly at the high school. At the school's office, Minister Radev, conversing in French, German and Russian, got into a discussion with the professors present there, asking friendly about working conditions, teaching results and asking about impressions from the trip of Polish teachers to Bulgaria. After visiting the physical laboratory, technical education shop and room for humanistic classes, the guests were cheered by the youth and went to the Palace of Fine Arts ${ }^{18}$. The stay at the Academy of Fine Arts lasted only 10 minutes. At that time, Professor Konstanty Laszczka ${ }^{19}$ presented his pieces of work to Minister Radev.

Around 2:00 p.m., Minister Todor Radev, accompanied by his associate Piriyov, paid a visit to the City Mayor, M. Kaplicki. After a longer conversation with the mayor, guests visited the town hall. Another element of the Bulgarian minister's stay in Krakow was a visit to Dom Związku Legionistów (House of the Legionnaires' Union) at Oleandry Street. The Minister was welcomed by, among others, Mikołaj Kwaśniewski, the Voivode (Governor) of the Krakow Region and at the same time President of the constituency of the Legionnaires' Union, accompanied by Deputy Presidents L. Strojek and Lt. Col. Podgórski. The Bulgarian delegation stayed longer during the visit in Sala Kadrówki (Hall of the First Cadre Company), where there was a model of the Oleandry Street as of 1914 and the historical order of Józef Piłsudski from August 1914, cut in marble ${ }^{20}$.

The second day of Minister Todor Radev's stay was spent visiting Ojców and Wieliczka. On the way to Ojców, the ministers Radev and Jędrzejewicz stopped first in Bronowice, then in Szyce, where they visited Uniwersytet Ludowy (Folk High School). After a short stay in Ojców, both ministers went to Wieliczka, where they sightsaw the salt mine. "Illustrated Kuryer Codzienny" reported it in the following way: At the Daniłowicz Shaft building, school children and adolescents stood in rows, followed by scouts and delegations with banners. When the car with the guests arrived, the miners'band played the national Bulgarian anthem, and the Mayor Jagielski welcomed the guests in the presence of the Voivode, Dr. Kwaśniewski, the Starost, Dr. Wnęk and the Director of salterns, Starnawski. After the speech, little girls in Krakow folk costumes presented flowers to the guests. Having signed the memorial book, ministers along with their entourage went down to the mines, staying longer in the Sienkiewicz chamber, where during the afternoon

\footnotetext{
18 Ibidem, p. 16.

19 Ibidem.

20 “Min. Radew w ratuszu”, Ilustrowany Kuryer Codzienny 1935, no. 103, p. 16.
} 
tea, school children performed Polish national dances ${ }^{21}$. Both ministers were also granted commemorative albums with photos from the Wieliczka salt mine. At 9:40 p.m., the Bulgarian delegation left Krakow for Dziedzice, thus ending their stay in Poland.

The last accent of this visit was a telegram sent by Minister Todor Radev to Minister Wacław Jędrzejewicz, just before leaving Poland. It stated as follows: Before leaving the territory of Poland, I would like to express to Your Excellency my great satisfaction over the signing of the cultural convention, which will strengthen the friendly links between our countries. I am grateful for the warm welcome you provided for $m e^{22}$.

Under both this dispatch and the press releases and comments, it appears that this visit was of great importance to both countries.

\section{Visit of the Minister of Education of Sweden, Artur Engberg}

The visit of Minister Artur Engberg to Poland lasted four days. It was held from 6 to 9 June 1935. The above cited newspaper "Ilustrowana Republika" published the following announcement of this visit: Tomorrow [i.e. 6 June - P.G.] in the afternoon, the Swedish Minister of Education and Religious Denominations, Mr. Artur Engberg, accompanied by the Secretary of State of the Swedish Ministry of Education, Mr. Knöes, arrive in Warsaw to pay an official visit at the invitation of the Polish government. In the afternoon, Minister Engberg will be hosted at a breakfast by the Minister of Foreign Affairs, Beck. After visiting the central institute of physical education, Minister Engberg will take part in the ceremony of inauguration of the Swedish library in Warsaw, and then will head to Krakow by train. The agenda of the Minister Engberg's stay in Krakow will include visiting local schools and historical monuments of Krakow. After visiting Wieliczka, Minister Engberg will leave for Poznań, where, having visited the city on 9 June, he will depart by plane to $\operatorname{Berlin}^{23}$.

"Ilustrowany Kuryer Codzienny" published on the day of the arrival of Minister Artur Engberg to Poland, a short text appeared, announcing this cultural and educational event. There would be nothing interesting about it, if not for the fact that this text, as the only one, contained a brief biographic note about the Swedish Minister of Education. The author of this press release wrote about Artur Engberg as follows: Minister Engberg was born in 1888. Having graduated from the University of Uppsala, he started work as a journalist. In 1915 he worked in the editorial board of the journal "Arbetet" (Labour). In 1924, he became the editor-in-chief of the "Socialdemokraten" daily. Since 1917, Minister Engberg has been a member of the second House of Parliament and takes active part in political life, being appointed to important positions in the parliament and the party. He

\footnotetext{
21 "Min. Radew i min. Jędrzejewicz zwiedzili Ojców i Wieliczkę", Ilustrowany Kuryer Codzienny 1935, no. 104 , p. 18.

22 "Podziękowanie min. Radewa za gościnę w Polsce, Ilustrowany Kuryer Codzienny" 1935, no. 105, p. 17.

23 “Ministrowie szwedzcy w Warszawie”, Ilustrowana Republika 1935, no. 155, p. 2.
} 
was a member of the Riksdag's foreign affairs committee and the vice-president of the constitutional commission, as well as a member of commissions appointed by the government for the matters of the League of Nations as a member of the Swedish delegation. He has been a minister of public enlightenment and religious denominations since $1932^{24}$.

The aeroplane with the minister landed at the Okęcie Airport on 6 June 1935. The minister of education was accompanied by his deputy, Böjre Knöes. For the arrival of the Swedish Minister of Education awaited at the airport, inter alia, the Minister of Religious Denominations and Public Enlightenment, Wacław Jędrzejewicz, deputy minister of this ministry, Fr. Bronisław Żongołłowicz and Professor Konstanty Chyliński. Also the Swedish Ambassador Boheman and Consul General Herslow were present there. After the welcome ceremony, the minister, accompanied by people waiting for his arrival, went to the hotel for rest ${ }^{25}$. It should be noted, however, that the flight had a stopover in Poznań, where Doctor E. Zdrojewski and representatives of the Poznań municipal authorities greeted Minister Engberg on behalf of the Ministry of Religious Denominations and Public Enlightenment ${ }^{26}$.

After the welcome, Minister Engberg went to the private apartments of the Swedish ambassador Erik Boheman, where he was hosted at a dinner. Also present were: Minister W. Jędrzejewicz, Deputy Minister, Fr. B. Żongołłowicz and professors K. Chyliński, Pieńkowski, Warchałowski, Jeliński, Handelsman, Antoniewicz, Łempicki, Tatarkiewicz, President of the Polish-Swedish Society Pawlikiewicz and several other people from the University of Warsaw and the Swedish diplomatic mission ${ }^{27}$.

Minister Artur Engberg spent the second day of the visit in Warsaw. A fairly detailed account of this visit was described in the "Dziennik Poznański" daily. Even the hours and minutes of meetings were given. Here is an excerpt: The Swedish Minister of Education and Confessions Artur Engberg and Undersecretary of State B. Knoes paid, yesterday at 9 a.m., a visit to the Minister of Education, Wactaw Jędrzejewicz. At 9:20, Minister A. Engberg, Ministers W. Jędrzejewicz and Knoes visited a 7-class public elementary school, Józef Bem School No. 183. Then the Swedish guests visited the state institute of handicraft. After laying the wreath on the tomb of the Unknown Soldier, the Swedish ministers went to Belweder (Belvedere Palace in Warsaw), where they signed the funeral book, paying homage to the memory of the Head of the Nation, Marshal Józef Pitsudski. At 12:40 the Swedish ministers were received by the President of the Council of Ministers, $W$. Stawek, and at 1 p.m. by the President of the Republic of Poland, and then visited the Royal Castle. At 1:30 p.m., in the apartments of the Minister of Foreign Affairs a proto-

24 "Szwedzki minister oświaty przybędzie do Warszawy i Krakowa", Ilustrowany Kuryer Codzienny 1935, no. 155 , p. 15 .

\footnotetext{
25 "Szwedzki minister oświaty w Warszawie", Gazeta Lwowska 1935, no. 130, p. 1.

${ }^{26}$ E. Z., "Pobyt w Polsce szwedzkiego ministra oświaty", Oświata i Wychowanie 1935, no. 6, p. 449.

27 “Minister Engberg w Warszawie”, Kurier Warszawski 1935, no. 155, p. 3.
} 
col was signed for establishing the principles of cultural cooperation between Poland and Sweden. Then, Minister Beck hosted the Swedish guests at a breakfast ${ }^{28}$.

The above-mentioned visit in the seven-grade General Józef Bem Elementary School No. 183 looked as follows, according to the description of journalists of the "Kurier Warszawski": The school choir sang the Swedish and Polish anthems. The guests were present during classes, and afterwards they visited the exhibition of pupils 'pieces of work at school. After the Swedish guests signed the memorial book, children gave them souvenirs made by the children themselves. The farewell performance was given by children with Swedish flags, cheering in Swedish "Leve sverige"29.

After the visit at Minister J. Beck, the Swedish delegation went to Centralny Instytut Wychowania Fizycznego (the Central Institute of Physical Education). The last item of the visit agenda was the opening ceremony of the Swedish library, located at Królewska Street 3. It commenced at 5:20 p.m., and the opening address was given by Professor Coleman - a Swedish language teacher working in Warsaw. In his speech, he emphasized the interest, increasingly visible in Poland, in the problems of social and cultural life in Sweden. In turn, Minister Engberg expressed his satisfaction and the fact of opening the library, and the fact of signing the convention on mutual cultural cooperation, which would certainly contribute to the development of relations between the two countries ${ }^{30}$. He also stressed the fact of growing Polish interest in the life and cultural problems of Sweden ${ }^{31}$. Minister Engberg said: I am very pleased to open this library, which will be yet another expression of a cordial relationship between our nations. During my stay in Poland, I could admire how the great Polish nation was able to rebuild itself both in political but also cultural terms in a short time. Our relations have always been friendly, so their tightening during my current stay in Warsaw, which is of great importance to me, will be extremely useful. I take this opportunity to thank the Polish Minister of Education for the kind welcome I have received and for being kindly accompanied during this day so full of interesting and unforgettable events. I deeply believe that the protocol signed today will largely contribute to the strengthening of our cooperation, and the newly opened library will also be one of bricks to build the Polish-Swedish friendship ${ }^{32}$.

On that day the cultural agreement between Poland and Sweden was signed. Under this agreement, both countries declared a firm wish to develop and strengthen mutual relations in the scientific, literary and art fields. This agreement was also intended to facilitate the research on the history of Polish-Swedish relations. Both in Poland and Sweden, special commissions were to be set up with the purpose to organize scientific exchange, to

\footnotetext{
28 "Konwencja o współpracy kulturalnej między Polską a Szwecją", Dziennik Poznański 1935, no. 133, p. 2.

29 “Minister Engberg w Warszawie”, Kurier Warszawski 1935, no. 156, p. 3.

30 “Konwencja o współpracy", op. cit., p. 2.

31 “Minister Engberg w Warszawie”, Kurier Warszawski 1935, no. 156, p. 3.

32 "Co mówi min. Engberg o swych wrażeniach w Warszawie", Ilustrowany Kuryer Codzienny 1935, no. 158 , p. 14.
} 
facilitate Polish scientists to give lectures in Sweden and vice versa, to facilitate Swedish representatives of academia to give lectures in Poland ${ }^{33}$.

The specialist journal "Oświata i Wychowanie" issued by the Ministry of Religious Denominations and Public Enlightenment published a brief account of the visit of Minister Engberg to Poland. It contained a quite detailed description of the individual items of agenda of these visits. Here is a fragment of this account concerning the exchange of distinctions between the Swedish delegation and the representatives of the Polish Ministry of Education: On 7 June, after a visit to Minister W. Jędrzejewicz, during which Deputy Minister Knös was awarded by the Minister of Religious Denominations and Public Enlightenment a Commander's Cross with Star of the Order of Polonia Restituta, and Minister Engberg decorated Minister Jedrzejewicz with a great ribbon of the Order of the Polar Star, and decorated Counsellor Zdrojewski a Commander of the Royal Order of Vasa, the Swedish guests together with the ambassador of Sweden Boheman in the company of Minister Jedrzejewicz, director Mendys, Superintendent Pytlakowski and Counsellor Zdrojewski, visited Państwowy Instytut Robót Ręcznych (the National Institute of Handicraft) at Górczewska Street 8 and the elementary school at Bema Street $76^{34}$.

In the evening, Minister Engberg in the company of Minister Jędrzejewicz left for Krakow. He arrived in Krakow less about half an hour before midnight.

Before the Swedish delegation went to Krakow, one of the journalists cooperating with "Ilustrowany Kuryer Codzienny" managed to briefly interview both Minister Engberg and Minister Jędrzejewicz. The Swedish minister expressed his impressions like this: I am delighted about my stay in Warsaw. I saw the school of handicrafts, the central Institute of Physical Education, I paid a visit to the President of the Republic of Poland, who kindly welcomed me, as well as to the President of the Council of Ministers. The ministers of foreign affairs and public enlightenment have received me as cordially as possible. It was a great pleasure to me to find a very high level of the institute of handicraft and the Józef Bem elementary school I visited, and it was a moving surprise for me that the children greeted me with a shout "Let Sweden live" in Swedish, and then they sang our national anthem in Swedish so faultlessly and with such a perfect accent that I simply did not believe my ears. The lesson was also devoted partly to Sweden, and the teacher translated it into Swedish for me. I met so much liking from both official and private people that I am deeply moved. I am very pleased to say that we have successfully signed a protocol on the extension of cultural relations between our nations, which offers broad opportunities for extensive cooperation within the framework of this protocol. I believe that all these things will be immeasurably useful for the future development of our cultural relations. I would like to reiterate that I was impressed by the central institute of physical education in Bielany, and that I consider it a model for such an institution. I deeply regretted that my visit occurred during the period of national mourning, which united all of Poland. It was not difficult to feel how strongly the fate of Poland was linked with the late Father

\footnotetext{
33 E. Z., "Pobyt w Polsce", op. cit., p. 449.

34 Ibidem, p. 449.
} 
of Poland's rebirth and how deeply did the Polish nation feel that death, regardless of social stratification ${ }^{35}$.

Minister W. Jędrzejewicz, who appeared a moment later at the station, also gave an interview. Among other things, he expressed satisfaction with the fact that the visit took place, and also that the Polish-Swedish cultural agreement was successfully signed. He considered the Swedish minister's visit as another element to make the friendship between both countries closer. He also announced his visit to Stockholm. Jędrzejewicz also stressed that he intends to show Minister Engberg, during the last two days of his visit to Krakow and Poznań, other interesting sites so that he could get the best possible "education-related and cultural" experiences ${ }^{36}$.

On 8 June 1935, Minister Engberg visited the Wawel Castle in the company of W. Jędrzejewicz. Accompanied by Superintendent Godecki, they visited the St. Mary's Church, the National Museum and the Jagiellonian Library. Later in the day, the Swedish delegation visited Szkoła Przemysłowa (Industrial School) and the high school at Oleandry Street.

The visits in both educational institutions were reported by "Ilustrowany Kuryer Codzienny". This article informs that the visit to the State Industrial School began at 9:50 a.m. The Swedish minister and other guests were greeted by the headmaster of this institution, Eng. Kostecki. After the welcome ceremony, the school workshops were visited. At the end of the visit, the headmaster handed to A. Engberg special folders decorated with Krakow folk-inspired ornaments, containing pieces of work made by the students. The next item of the agenda was a visit to the girls' high school. Then the Swedish guests went to the Queen Wanda High School at Oleandry Street, where they were greeted by the headmistress, Ms. Józefa Bergruen. The Ministers along with accompanying gentlemen passed along a line of young people standing on the stairs, some of whom were wearing Krakow folk costumes, then the guests passed to the school auditorium. At the entrance to this hall, the school choir sang the Polish anthem "Jeszcze Polska nie zginęla", after which student Bandrowska asked the Swedish guests to receive greetings addressed to the Swedish youth. The students presented flowers to the ministers and accompanying gentlemen, and then the choir sang the Swedish anthem in Swedish. Upon leaving, the Swedish Minister expressed his gratitude for the welcome, appreciating the value of girls' schools, stating that girls' schools educate future mothers, and thus future generations. The Swedish guests stayed in the girls' high school for 45 minutes $^{37}$.

Having visited the educational establishments, the representative of the Swedish government paid a visit to the Mayor of Krakow, Kaplicki. Minister Jędrzejewicz held a breakfast in Grand Hotel in honour of the Swedish guest. Then Minister Engberg laid a wreath at the Marshal Piłsudski's coffin at the Wawel Castle. He also took part in building the

\footnotetext{
35 "Co mówi min. Engberg o swych wrażeniach w Warszawie”, op. cit., p. 14.

36 Ibidem, p. 14.

37 “Dzień szwedzkiego ministra oświaty w Krakowie”, Ilustrowany Kuryer Codzienny 1935, no. 159, p. 7.
} 
Marshal Piłsudski’s mound in Sowiniec. In the afternoon, representatives of the Swedish and Polish ministries of education went to Wieliczka, where they visited the Wieliczka salt mine. At 22.00 the Swedish minister of education, accompanied by his associates, went on a trip to Poznańn ${ }^{38}$.

Minister Engberg spent the last day of his stay in Poland in Poznań. It is difficult to say whether it was of much importance to the residents of Poznań. As far as press accounts are concerned, "Kurier Poznański" informed about it on the seventh page of the main issue of 12 June 1935, that is three days after the minister left Poznań. The note was very brief: On the first holiday in the morning, the Swedish Minister of Education, Mr. James Artur Engberg and the Deputy Minister of education, Mr. Knöes, came from Krakow to Poznan for a short stay. In the morning, the guests visited the exhibition at Szkoła Zdobnicza (the School of Decorative Design). After visiting the Museum of the Town Hall and the building of anatomy department, they left for Stockholm via Berlin ${ }^{39}$. In the text placed in the bottom left corner of the column, a photo of the minister was also published.

"Dziennik Poranny" referred to this in more detail, informing that the Swedish delegation appeared at the Poznań train station at nine o'clock in the company of Minister W. Jędrzejewicz. After the welcome, the delegation started sightseeing the city, mainly schools and other educational institutions. Minister Engberg visited the handwork studio in the Berger state high school and the exhibition of paintings at the state school of decorative arts. He also visited the school botanical garden and the construction site of the state gardening school. It was also announced that the Swedes would visit the castle of Kórnik $^{40}$. In fact, however, only representatives of the Polish Ministry of Finance led by Minister Jędrzejewicz went to Kórnik ${ }^{41}$.

Readers of "Dziennik Poznański" had the opportunity to learn about the course of the visit by means of an iconographic message, which was quite clever. In the issue 132 of 8 June, the first page contained a photograph with the following subtitle: Yesterday, Poznan' 's Airport of Ławica hosted, for a 20-minute stopover, the Swedish Minister of Education, Mr. Jones Artur Engberg (in the upper circle) and the Deputy Minister of Education Mr. Bödie Olaf Knoes. The ministers were welcomed, among others, by Honorary Swedish Consul in Poznań, Mr. Legis ${ }^{42}$.

The last day of the minister's stay in Poznań was commented in a similar manner. A picture of the departing plane with Minister Engberg was published, decorated with small photographs placed in the corners of the main photograph. One of them depicting the

\footnotetext{
38 “Szwedzki minister oświaty w Krakowie”, Czas 1935, no. 157, p. 2.

39 “Szwedzki min. Oświaty w Poznaniu”, Kurier Poznański 1935, no. 265, p. 7.

40 "Ministrowie szwedzcy w towarzystwie min. Jędrzejewicza przybywają dziś do Poznania", Dziennik Poranny 1935, no. 84, p. 4.

41 “Ministrowie szwedzcy zwiedzili Poznań”, Dziennik Poranny 1935, no. 85, p. 4.

42 “Ministrowie szwedzcy na lotnisku w Lawicy”, Dziennik Poznański 1935, no. 132, p. 1.
} 
welcome of the minister at the railway station in Poznan, while the second showing the Swedish delegation just before departure ${ }^{43}$.

Another fact should be noted here. A few days before the Minister Engberg's arrival in Poznan, the city had held, at the initiative of the Polish-Swedish Association operating in the capital of Wielkopolska, a solemn meeting, the purpose of which was to celebrate the national holiday of Sweden. At the outset, the President of the Association, Mr. A. Mueller, expressed wishes for the successful development of the Swedish nation and their king. Then the speaker referred to increasingly stronger Polish-Swedish relations, filled with mutual friendship and fellow feelings, and mentioned the useful activity of the Polish-Swedish Association in terms of rapprochement between both nations ${ }^{44}$. The participants listened to two more lectures concerning the five hundredth anniversary of the Swedish parliament and suburban housing development in Sweden. The meeting gathered many people. Although the forthcoming visit of the Swedish Minister of Education was not even mentioned, at least the press failed to notice it, however it must be said that such a meeting was a perfect introduction to this visit and for its observation not only by residents of Poznań.

Upon leaving Poland, the minister expressed his satisfaction with the visit. In an interview with the journalist, he noted that he was extremely moved by the warm reception. He was touched by Swedish flags hung in the cities and places he had visited. The Polish schools also had a great impression on him. He also expressed his hope for a return visit by Minister W. Jędrzejewicz in September $1935^{45}$.

\section{Visit of the Minister of Education of Hungary, Bálint Hóman}

The last minister of education who visited Poland in 1935 was a representative of the Hungarian government, Bálint Hóman. He was not the first Hungarian minister of this ministry to visit the Republic of Poland. Four years earlier, Minister Kuno Klebersberg had visited Poland. At that time the Polish Ministry of Religious Denominations and Public Enlightenment was led by Sławomir Czerwiński.

The visit of the Hungarian minister had a slightly different purpose than the two described above. The declaration of cooperation was signed already in 1934, and Bálint Hóman came to Poland to summarize the first year of its functioning. This visit differed also in terms of the agenda. Apart from Warsaw and Krakow, the Minister also visited Vilnius. He began his visit in Poland on 3 November 1935 (in Warsaw), and ended on 9 November (in Krakow).

On the eve of this visit, a comprehensive article written by the Hungarian minister himself was published in the "Ilustrowany Kurier Codzienny" daily, entitled "Poland and

\footnotetext{
43 “Z pobytu szwedzkich ministrów w Poznaniu”, Dziennik Poznański 1935, no. 134, p. 1.

44 “Uroczyste zebranie z okazji święta narodowego Szwecji”, Dziennik Poranny 1935, no. 82, p. 4.

45 “Min. Engberg powrócił do Sztokholmu”, Czas 1935, no. 159, p. 2.
} 
Hungary as two bastions of the Western civilization". This text was a fairly detailed and in-depth analysis of Polish-Hungarian relations over the centuries. It began with the legendary reconciliation of both nations in the period of Saint Stephen: according to a legend, this nation that would break friendship risked being excommunicated. It concluded with a description of the contemporary situation of both countries ${ }^{46}$.

On the first day of the Minister Hóman's visit to Poland, an article actually presenting the biography of the Hungarian minister of education appeared in the Krakow's daily "Czas". It was written by Jan Dąbrowski. He referred to Hóman as the most eminent Hungarian scholar. The Hungarian Minister of Education was a historian by education and found recognition owing to his excellent studies on medieval history, especially in the economic context, as well as on sources for Hungarian history. According to Dąbrowski, the best Hóman's works included those regarding the financial practice of Charles of Anjou and Hungary's finances, while the History of Hungary, co-written with Professor Szekfü, was considered by him as the most important Hóman's publication. Before taking the post of minister, Bálint Hóman was a lecturer at the chair of Hungarian history at the University of Budapest and at the same time the director of the Hungarian National Museum. The author described the activities of Bálint Hóman as the Minister of Education: As the Minister of Education, Professor Hóman both cared for the proper level of education, especially secondary education, and for the needs of science and higher education, and managed to successfully solve difficult problems caused by the need to cut costs in the times of depression, by providing the funds needed for the development of science, such as universities, whose achievements are today deservingly the pride of Hungary. The Professor Hóman's research interests also led him to become familiar with many issues of Poland's past; he has always showed great understanding and support for scientific relations with Poland, and his visit to Poland is yet another affirmation of this for $\mathrm{us}^{47}$.

The first day of the official visit was 4 November 1935. It can be described as an intensive, but quite pleasant day. The agenda of the day, as summarized in "Oświata i Wychowanie", was as follows: The guests began their first day of stay, on 4 November, by paying a visit to the head of the Ministry of Religious Denominations and Public Enlightenment, where Minister Hóman decorated Minister Chyliński with the Great Ribbon of the Hungarian Order of Merit, and Minister Chylinski decorated Minister Hóman and Secretary of State Szilly with the Grand Ribbon of the Order of Polonia Restituta, Supervisor Villani with the Gold Cross of Merit and Councillor Terbocs with Commander Cross of the Order of Polonia Restituta. Then the guests along with Minister Chylinski, Director Mendys, Superintendent Pytlakowski, Supervisor Maciszewski and Counsellor Zdrojewski went to visit the Batory High School. Having received the return visit of Minister Chylinski, Minister Hóman laid a wreath on the Tomb of the Unknown Soldier, then he went to Mr. Szembek, Deputy Minister of Foreign Affairs, who hosted a breakfast in his honour. In the

46 "Polska i Węgry dwoma bastionami zachodniej cywilizacji", Ilustrowany Kurier Codzienny 1935, no. 306, pp. 3-4.

${ }^{47}$ DĄBROWSKI, J., "Prof. dr Hóman węgierski minister oświaty”, Czas 1935, no. 303, p. 6. 
afternoon, the inauguration of the Hungarian Institute was held, and in the evening a dinner and evening reception hosted by Minister Chylinski ${ }^{48}$.

As soon as on the first day of the visit, Bálint Hóman was granted by the Józef Piłsudski University of Warsaw the title of honorary doctor in philosophy. The ceremony gathered representatives of the Polish Ministry of Religious Denominations and Public Enlightenment, the Hungarian embassy and, naturally, the scholarly community. The Minister himself and his services for historical studies were characterized by Professor Handelsman, who also stressed the Hóman's contribution to the development of PolishHungarian relations at the scientific and cultural level. The speaker said that as a recognition of merits of Minister Hóman for the development of Hungarian research on PolishHungarian relations, the Józef Pitsudski University had decided to award him a honorary doctorate in philosophy ${ }^{49}$. Then Professor Antoniewicz read out the diploma and handed it to Bálint Hóman. The Hungarian Minister of Education thanked in Latin for this honourable mention. He also said that this ceremony would be a link in the golden chain which will eternally bind the culture of humanitarianism of Poles and Hungarians, as well as the mutual friendship of both nations affected by so many disasters ${ }^{50}$. After the ceremony, Rector Pieńkowski hosted the Hungarian minister at a breakfast held in Resursa Kupiecka (The Warsaw Businesss Social Club).

An important element of the visit of the Hungarian Minister of Education was the ceremony of opening the Hungarian Institute, which was one of many elements of the implementation of the cultural agreement signed a year earlier between the two countries. The ceremony, which took place in the column hall of the Staszic Palace (headquarters of the Institute), gathered a large number of representatives of the community of scholars, Polish educational authorities and members of the Hungarian delegation led by Minister Bálint Hóman The first speaker was Professor Sierpiński, who in a speech given in French welcomed the Hungarian guest and expressed his delight about the fact that the Institute was opened. Professor Diveky asked Minister Hóman to open the Hungarian Institute. On this occasion, the Hungarian Minister of Education gave a speech in Latin, in which he spoke about the inseparable bonds linking Poland and Hungary. After the Institute opening ceremony, his boss, Professor Diveky, who in a lecture delivered in Polish presented an insight about the history of Polish-Hungarian relations over several centuries. He said, among other things: The Jagiellonian University was a Mecca for the Hungarian youth. At the end of the 15 century, 17 percent the students of this University were Hungarians who had their own dormitory and chapel in Krakow. The first books in Hungarian, including the first Hungarian grammar, were printed in Krakow. The sculpting school of Veit Stoss (Wit Stwosz) spread its influence to Hungary. There are numerous similarities in the field of state organization and legislation. Unfortunately, the rapprochement cannot be duly pro686

48 E. Z., "Pobyt w Polsce węgierskiego ministra oświaty", Oświata i Wychowanie 1935, no. 8-9, pp. 685-

49 "Węgierski minister oświaty w Warszawie", Kurier Warszawski 1935, no. 305, p. 3.

50 Ibidem, p. 3. 
moted, for the lack of more thorough knowledge about Hungary among Poles. So far, we have not had any good textbooks to learn Polish for Hungarians and Hungarian for Poles. There is also no Polish-Hungarian dictionary published to this date. Translations of literary works are often made from German. That is why they still contain failures and shortcomings. The aim of the Institute will be to enable Poles interested in the history and culture of Hungary to get relevant sources. The Institute has a library which will be supplied with new items by Hungarian institutions. At the Institute, Polish scholars will find help in studying various fields of research ${ }^{51}$.

Minister Hóman noted several important aspects when speaking about the visit to Poland. In an interview given to journalists of the Polish Telegraph Agency, he said: The Polish and Hungarian nations had previously been tied with political bonds only. Later on, an economic agreement was concluded, and recently the previous agreements were complemented by the conclusion of a cultural agreement, signed by the heads of government of both states on 21 October 1934 and subsequently ratified by both parliaments. The purpose of my trip to the Polish capital is to implement this framework agreement or, to be more precise, to prepare practical work. The second purpose of my stay here is to learn about all kinds of solutions applied to serve Polish culture, education and modern Polish cultural policy. Besides, I can say it openly, I was delighted to come to Poland as this gave me the opportunity to complete all the knowledge I acquired during my studies on the whole of Polish-Hungarian relations. I consider my journey as successful in terms of each of these three reasons, I welcome everything I saw here with the greatest appreciation. I would also like to thank you for the warm reception and cordial hospitality. I am particularly grateful to the President of the Council of Ministers, Mr. Kościatkowski, Minister of Education Chylinski and the Deputy Minister, Fr. Żongołtowicz, who offered me their support in anything I did. I am deeply convinced that this friendly contact will be a new step towards deepening and strengthening our friendship. During my conversations and meetings, as well as during visits to Warsaw cultural institutions, I became convinced that Polish cultural policy, fully aware of its goals, deals with the matter of school policy which is a topical issue throughout Europe. I noticed in this new system of schools, i.e. managers of this system, the same basic ideas and views that were followed in the reform of education in Hungary. The goals and objectives here are the same as in our country. I have also noticed the care that the culture of young people learning in various schools and having different social background be based on a common basis and that these young people preparing to perform various occupations be provided with broad general education. As a historian, I was deepest impressed by a conversation with the historical personality of the Polish state, President Ignacy Mościcki. As a private man, I felt deeply moved while being awarded an honorary doctorate at the Józef Pitsudski University. Finally, as a Minister of Education, I was delighted with the excellent preparation of students and up-to-date teaching methods at the Stefan Batory high school, and also the teaching system used in the Bem primary school which corresponds to the spirit of our times, and finally - the magnificent organization of the Central Institute of Physical Education, which

51 "Uroczyste otwarcie Instytutu Węgierskiego", Ilustrowany Kurier Codzienny 1935, no. 308, p. 3. 
I always will keep in mind with admiration. I am glad that thanks to the kindness of my Polish colleague I had the opportunity to get acquainted with everything and that in this way I will be able to use the experience gained here in my further activity as the Minister of Education ${ }^{52}$.

The above suggests that Minister Hóman was generally satisfied with his visit to Poland and meetings in educational institutions. The statement seems to be honest and should not be perceived as mere courtesy or diplomatic correctness. It is noteworthy that the Hungarian Minister of Education visited the institutions bearing the names of people associated with the history of Hungary - Stefan Batory and Józef Bem.

The press, or more specifically Krakow's “Czas", noted in quite detail yet another fact about the stay of Minister Hómana in Warsaw. Namely, the Hungarian ambassador residing in Poland hosted a reception in honour of the Hungarian Minister of Education, held in the Rzyszczewski Palace (the seat of the Hungarian embassy in Warsaw). The atmosphere at this party was characterized as follows: As usual with our Hungarian friends, the atmosphere was lovely and everyone felt at home especially that Ambassador de Horya entertained us with genuine Hungarian hospitality. Excellent Hungarian wine, served abundantly and in many varieties, even enhanced this pleasant mood ${ }^{53}$. The author of this note, probably a participant in this reception, as a considerable number of journalists were invited, also described the attitude of Minister Hóman during this reception: Among the crowds of guests in beautiful rooms and lounges, we noticed above all the figure of the Hungarian minister of education, winning everyone with an extraordinary personal charm, unpretentiousness and careless humour. Rarely does such great erudition combine with such an outgoing character ${ }^{54}$. Then the author mentions presumably the most prominent guests participating in the party at the Hungarian embassy: ministers, diplomats, representatives of the clergy, scholars, writers, journalists and members of the Polish-Hungarian society.

Of the three ministers of education visiting Poland in 1935, only Bálint Hóman visited Vilnius. The visit took place on 7 November 1935. It began with paying tribute to the heart of Marshal Piłsudski in the St. Teresa's Church. Hóman was accompanied by several people, including Minister Chyliński. Later Hóman, in the company of Professor Moralewski and Fr. Puciaty, visited the chapel in Ostra Brama and several other churches, including St. Anna's and St. Peter and Paul's on Antokol. Another element of the agenda was visiting the university library and the Stefan Batory University itself. The Hungarian minister also climbed the Bekieszowa Hill, where according to the legend, Kasper Bekiesz had been buried, the commander of Hungarian troops from the time of King Stefan Batory. He also visited several school establishments, including the elementary school in Antokol and the Eliza Orzeszkowa High School. Then a meeting with former University rector Zdziechowski and other professors of the Vilnius University took place at 2:00 p.m. A quarter before 7:00 p.m. a welcome ceremony for the Hungarian and polish ministers of

\footnotetext{
52 "Min. Hóman o swoim pobycie w Polsce", Kurier Warszawski 1935, no. 306, p. 3.

53 “Raut w poselstwie węgierskim", Czas 1935, no. 307, p. 8.

${ }^{54}$ Ibidem, p. 8.
} 
education was held in the column hall of the Stefan Batory University. The orchestra of the 3rd Infantry Regiment and the academic choir together played and sang the anthems of both countries, while the speeches were given by the Rector of the University, Witold Staniewicz and President of Towarzystwa Przyjaciół Węgier (Association of Friends of Hungary) Marian Zdziechowski. After this ceremony, a dinner was served, and at 8:50 p.m. delegations from both ministries set out on a return journey to Warsaw ${ }^{55}$.

The next city on the Minister Hóman's tour in Poland was, as in the two previously described cases, Krakow. The representative of the Hungarian government arrived in this city on Friday 8 November, afternoon. The welcome ceremony at the Krakow railway station was very solemn and gathered many prominent residents of the royal town. In the reception lounge, girls' and boys' high school standard-bearers lined up. At the railway station, Minister Hóman was greeted by representatives of the local authorities, led by Acting Voivode Małaszyński, Deputy Mayor Klimecki and Deputy Rector, Professor Krzyżanowski and the Hungarian consul Dyduch. There were also members of the Polish-Hungarian Society with their president, Bishop Godlewski, Professor Sroczyński and members of the local Hungarian diaspora and Academic Society of Friends of Hungary ${ }^{56}$.

The first agenda item of the visit in Krakow was the breakfast hosted by the Hungarian consul, Dyduch. At 4:30 p.m., Bálint Hóman appeared in the Wawel Castle, where he laid a wreath at the coffin of Marshal Piłsudski and the Hungarian king Stefan Batory. He also visited the castle. He also met with Cardinal Sapieha. At 6:00 in the evening, a tea meeting was held in honour of Minister Hóman at the initiative of the Polish-Hungarian Society, Hungarians living in Krakow and the Academic Society of Friends of Hungary. On this occasion, a welcome speech was delivered by Bishop Godlewski, the president of the Polish-Hungarian Society. At the end of the meeting, Dr. Harajda spoke on behalf of the Academic Society of Friends of Hungary. He stressed that cultural cooperation between the two countries at the Jagiellonian University had existed ceaselessly since the beginning of the university, and that current students were constantly working to maintain and develop that cooperation, and to make both nations closer. The president of the Academic Society, Susułowska gave minister Hóman a decorated edition of Kazania Świętokrzyskie (Saint Cross Sermons). Bálint Hóman, when expressing thanks for this gift, said he was pleased that not only the older generation but also the youth work on maintaining and deepening the Polish-Hungarian relations. The first day of the visit to Krakow was concluded with a dinner held in honour of Minister Bálint Hóman by the Rector of the Jagiellonian University, Professor Maziarski ${ }^{57}$.

The last day of the visit in Krakow and in Poland as well began quite early in the morning and was full of events. The Hungarian minister was accompanied on this day by Polish Deputy Minister of Education, Fr. Bronisław Żongołłowicz, who came from Warsaw especially on this occasion. The delegation of both ministries visited the university building,

\footnotetext{
55 "Węgierski minister oświaty w Polsce”, Kurier Warszawski 1935, no. 307, p. 3.

56 "Węgierski minister oświatowy w Krakowie”, Ilustrowany Kurier Codzienny 1935, no. 312, p. 18.

${ }^{57}$ Ibidem, p. 18.
} 
the Jagiellonian Library and the state Queen Wanda High School. Minister Bálint Hóman also met with the secretary general of Polska Akademia Umiejętności (Polish Academy of Arts and Sciences), Professor Kutrzeba. Even before noon, he went to Sowiniec, where he took part in mounding the mound in honour of Marshall Józef Piłsudski. Having returned from Sowiniec, the Hungarian guest visited the Czartoryski Museum and then paid a visit to Professor. Jan Dąbrowski and his wife. The last item of the agenda was a dinner hosted by Voivode Małaszyński in honour of Minister Hóman. In the evening, the minister seen off by local and academic authorities, left Krakow and set off for Budapest. He was accompanied by Deputy Minister B. Żongołłowicz to the Czechoslovak border ${ }^{58}$.

The year 1935 was therefore special for Polish foreign contacts in the field of education and culture. The three ministers of education visiting Poland for specific purposes: signing cultural agreements and evaluating their implementation, were extremely important for the still reviving Polish school system and Polish science looking for good solutions. These visits strengthened Poland's position in the international arena also. Thus, Poland gained new allies, new partners, also those in the field of shaping educational relations.

When analysing the course of the visits described above, one needs to pay attention to a few details. The agenda of the visits was similar. All the three ministers visited Warsaw and Krakow. In Warsaw, all of them laid wreaths at the Tomb of the Unknown Soldier and visited the Central Institute of Physical Education. In Krakow, they visited the Jagiellonian Library and nearby town of Wieliczka. The Ministers of Sweden and Hungary also paid tribute to Marshal Piłsudski, whose body rested in the crypt of Saint Leonard in the Wawel Castle and took part in building the Piłsudski's mound at the Krakow's district of Sowiniec. Minister Radev visited Poland when the Marshal was still alive, although he did not meet with him.

The accumulation of these visits in one year may indicate that Poland tried to consolidate its position in Europe by establishing various forms of cooperation with other countries. An important role was also played by matters of education and culture. The ministers of education from Bulgaria and Sweden came to Poland to conclude cultural agreements between their countries and the Republic of Poland. In turn, the Hungarian representative of the Ministry of Education aimed at verification of the implementation of such agreement, signed by Poland and Hungary a year earlier.

This paper has also the nature of a chronicle, hence the large number of quotes and names, perhaps not known to some of the readers. This approach stems from the fact that most archival sources which could illustrate the course of these visits, important for the Polish education of the Second Polish Republic, have not survived, and even if survived they are incomplete.

\footnotetext{
58 “Minister Hóman opuścił Kraków”, Czas 1935, no. 309, p. 4.
} 


\section{Bibliography}

„Bułgarski minister oświaty przybył wczoraj do Polski”, Ilustrowana Republika 1935, no. 97, p. 2. „Bułgarski minister przyjeżdża do Warszawy”, Ilustrowana Republika 1935, no. 96, p. 3.

„Co mówi min. Engberg o swych wrażeniach w Warszawie”, Ilustrowany Kuryer Codzienny 1935, no. 158, p. 14.

DĄBROWSKI, J., „Prof. dr. Hóman węgierski minister oświaty”, Czas 1935, no. 303, p. 6.

„Dzień szwedzkiego ministra oświaty w Krakowie”, Ilustrowany Kuryer Codzienny 1935, no. 159, p. 7.

E. Z., „Pobyt w Polsce szwedzkiego ministra oświaty”, Oświata i Wychowanie 1935, no. 6, p. 449.

E. Z., „Pobyt w Polsce węgierskiego ministra oświaty”, Oświata i Wychowanie 1935, no. 8-9, pp. 685-686.

GOŁDYN, P., Wizyta ministra oświaty Rumunii Constantina Angelescu w Polsce w 1937 r. w świetle ówczesnych doniesień prasowych, [in:] Polsko-rumuńskie zwiazki historyczne i kulturowe, ed. S. IACHIMOVECHI, E. WIERUSZEWSKA-CALISTRU, Suceava 2013.

„Konwencja o współpracy kulturalnej między Polską a Szwecją”, Dziennik Poznański 1935, no. 133, p. 2.

KORDECKI, K., „Polska-Bułgarja”, Dziennik Poznański 1935, no. 83, p. 3.

MICHALSKA, I., Wybrane problemy metodologiczne wykorzystywania prasy jako źródła w badaniach historii wychowania, [in:] Źródła w badaniach naukowych historii edukacji, ed. W. SZULAKIEWICZ, Toruń 2003, pp. 127-144.

„Min. Engberg powrócił do Sztokholmu”, Czas 1935, no. 159, p. 2.

„Min. gen. Radew i min. Jędrzejewicz przybyli do Krakowa”, Ilustrowany Kuryer Codzienny 1935, no. 102 , p. 16.

„Min. Homan o swoim pobycie w Polsce”, Kurier Warszawski 1935, no. 306, p. 3.

„Min. Radew i min. Jędrzejewicz zwiedzili Ojców i Wieliczkę”, Ilustrowany Kuryer Codzienny 1935 , no. 104 , p. 18

„Min. Radew w Polsce”, Kurier Warszawski 1935, no. 100, p. 3.

„Min. Radew w ratuszu”, Ilustrowany Kuryer Codzienny 1935, no. 103, p. 16.

„Min. T. Radew w Warszawie”, Kurier Warszawski 1935, no. 98, p. 3.

„Minister bułgarski w najstarszem gimnazjum Polski”, Ilustrowany Kuryer Codzienny 1935, no. 103, p. 16.

„Minister Engberg w Warszawie”, Kurier Warszawski 1935, no. 155, p. 3.

„Minister Engberg w Warszawie”, Kurier Warszawski 1935, no. 156, p. 3.

„Minister Hóman opuścił Kraków”, Czas 1935, no. 309, p. 4.

„Minister Radew gościem Rządu polskiego”, Dziennik Poznański 1935, no. 83, p. 3.

„Ministrowie szwedzcy na lotnisku w Ławicy”, Dziennik Poznański 1935, no. 132, p. 1.

„Ministrowie szwedzcy w towarzystwie min. Jędrzejewicza przybywają dziś do Poznania”, Dziennik Poranny 1935, no. 84, p. 4.

„Ministrowie szwedzcy w Warszawie”, Ilustrowana Republika 1935, no. 155, p. 2.

„Ministrowie szwedzcy zwiedzili Poznań”, Dziennik Poranny 1935, no. 85, p. 4.

„O ożywienie wymiany kulturalnej polsko-bułgarskiej”, Dziennik Poznański 1935, no. 84, p. 2.

„Oświadczenie min. Radewa”, Czas 1935, no. 98, p. 2.

„Pierwszy dzień pobytu”, Czas 1935, no 98, p. 2.

„Podpisanie polsko-bułgarskiej umowy kulturalnej”, Goniec Częstochowski 1935, no. 84, p. 3.

„Podziękowanie min. Radewa za gościnę w Polsce”, Ilustrowany Kuryer Codzienny 1935, no. 105, p. 17.

„Polska i Węgry dwoma bastionami zachodniej cywilizacji”, Ilustrowany Kurier Codzienny 1935, no. 306 , pp. 3-4. 
„Raut w poselstwie węgierskim”, Czas 1935, no. 307, p. 8.

„Szwedzki Min. Oświaty w Poznaniu”, Kurier Poznański 1935, no. 265, p. 7.

„Szwedzki minister oświaty przybędzie do Warszawy i Krakowa”, Ilustrowany Kuryer Codzienny 1935 , no. 155 , p.. 15.

„Szwedzki minister oświaty w Krakowie”, Czas 1935, no. 157, p. 2.

„Szwedzki minister oświaty w Warszawie”, Gazeta Lwowska 1935, no. 130, p. 1.

„Uroczyste otwarcie Instytutu Węgierskiego”, Ilustrowany Kurier Codzienny 1935, no. 308, p. 3.

„Uroczyste zebranie z okazji święta narodowego Szwecji”, Dziennik Poranny 1935, no. 82, p. 4.

„Węgierski minister oświatowy w Krakowie”, Ilustrowany Kurier Codzienny 1935, no. 312, p. 18.

„Węgierski minister oświaty w Polsce”, Kurier Warszawski 1935, no. 307, p. 3.

„Węgierski minister oświaty w Warszawie”, Kurier Warszawski 1935, no. 305, p. 3.

„Z pobytu szwedzkich ministrów w Poznaniu”, Dziennik Poznański 1935, no. 134, p. 1.

Originally published in "Biuletyn Historii Wychowania", 2014, vol. 31, pp. 207-227 
